\title{
Social representations of climate change in Swedish lay focus groups: Local or distant, gradual or catastrophic?
}

\author{
Victoria Wibeck \\ Linköping University Post Print \\ Tweet \\ N.B.: When citing this work, cite the original article.
}

Original Publication:

Victoria Wibeck, Social representations of climate change in Swedish lay focus groups: Local or distant, gradual or catastrophic?, 2014, Public Understanding of Science, (23), 2, 204-219. http://dx.doi.org/10.1177/0963662512462787

Copyright: SAGE Publications (UK and US)

http://www.uk.sagepub.com/home.nav

Postprint available at: Linköping University Electronic Press

http://urn.kb.se/resolve?urn=urn:nbn:se:liu:diva-85135 
Social representations of climate change in Swedish lay focus groups: local or distant, gradual or unpredictable?

Victoria Wibeck

Department of Thematic Studies - Unit of Water and Environmental Studies /Centre for Climate Science and Policy Research, Linköping University

58183 Linköping, Sweden

Corresponding address: victoria.wibeck@liu.se

Abstract:

This paper explores social representations of climate change, investigating how climate change is discussed by Swedish laypeople interacting in focus group interviews. The analysis focuses on prototypical examples and metaphors, which were key devices for objectifying climate change representations. The paper analyzes how the interaction of focus group participants with other speakers, ideas, arguments, and broader social representations shaped their representations of climate change. Climate change was understood as a global but distant issue with severe consequences. There was a dynamic tension between representations of climate change as a gradual vs. unpredictable process. Implications for climate change communication are discussed.

Keywords: climate change, social representations, focus group, interaction, objectification, metaphor 


\section{Introduction}

Climate change is increasingly seen as a major threat to humanity, affecting the general public across the globe, and its anthropogenic causes are now acknowledged by the vast majority of scientists (Schneider, 2011). Notwithstanding, the topic of climate change is difficult for most laypeople to understand, since it is "both temporal (long term and developmental) and unseen (not always visible)" (Doyle, 2007: 129). Climate change involves multiple actors and knowledge systems and is characterized by conflicting values and epistemic authorities (Lorenzoni et al., 2007a: 66). Various views of how laypeople can best help mitigate and adapt to climate change effects are articulated in the scientific and political debate. This has led social scientists to conclude that "for many members of the public, climate change is likely to be the ultimate ambiguous situation given its complexity and perceived uncertainty" (Nisbet, 2009: 16).

This paper aims to analyze how Swedish focus group participants make sense of climate change. It investigates how climate change is discussed by lay participants in focus group interviews and analyzes how the participants objectify the complex issue of climate change, i.e. how they make it concrete and tangible. The paper further explores the role of interaction in forming and maintaining social representations of climate change. Implications for climate change communication are discussed.

The study is prompted by the fact that considerable time and money are being invested in communicating the causes, effects, and response to climate change to the public, for example, through information campaigns organized by state agencies, NGOs, and the European Union. ${ }^{1}$

\footnotetext{
${ }^{1}$ Examples of such campaigns include the EU's Climate Action campaign (http://ec.europa.eu/climateaction/index_en.htm) and the Swedish Environmental Protection Agency's climate 
The research literature and politicians assume that laypeople play important roles in mitigating and adapting to climate change, as citizens and/or as consumers (UNEP, 2011; Wibeck, forthc.). Nonetheless, communicating climate change is not easy given the "multiple time and spatial scales of the problem, the ethical, social and cultural values involved in decisions, and the urgent need for concerted action to mitigate greenhouse gas emissions" (Carvalho, 2008: 8). Many earlier studies of climate change communication have focused on the role of the communicator, stipulating how communication activities should be organized or the type of content to be included to maximize effectiveness (e.g., Hassol, 2008; Moser, 2010). Studies of the public's understanding of climate change mainly analyze what people think, i.e., they focus on the content of lay perceptions of climate change (e.g., Eurobarometer, 2011; Leiserowitz et al., 2011). In contrast, fewer studies also pay attention to how laypeople make sense of climate change. In the words of Lowe et al. (2006: 436), "whilst lay perceptions of climate change and other environmental issues are relatively well understood, knowledge of the forces that shape the perceptions and responses of the public is limited."

The present study treats this knowledge gap, generating new understandings of the sensemaking processes involved as laypeople form and maintain social representations of climate change. The paper contributes with new knowledge on how lay people in Sweden - where climate change has been widely discussed in the media and where public awareness is high understand climate change. The paper argues that sense-making processes matter, since they shape the content of social representations. The paper also demonstrates that careful microlevel analysis is needed to capture the nuances involved in the public's understanding of 
complex and controversial topics such as climate change. The study is based on seven focus group interviews of Swedish laypeople conducted in autumn 2009 and spring 2010.

\section{Climate change inside and outside the Swedish context}

Climate change is a prominent issue in Swedish political and mass media debate. Swedish news media and tabloids have paid massive attention to climate change during the last few years (Berglez, 2011; Westander et al., 2008), framing climate change as a social problem and stressing the need for collective action (Olausson, 2009). Swedish news stories emphasize scientific certainty and start from the assumption that "human-induced global warming is a direct cause of climate change, bringing with it dramatic consequences already at hand" (ibid.: 429).

The 2011 Eurobarometer survey on climate change showed that across the EU countries, Swedish respondents were the most concerned about climate change. Other studies support the finding that Swedes generally consider themselves climate conscious, and increasingly state they have done something in their everyday lives to reduce their climate impact (SEPA, 2009; Westander et al., 2008).

Going outside the Swedish context, Lorenzoni and Pidgeon (2006) noted in a review of fifteen years of climate change perceptions research in Europe and the USA, that although climate change was perceived as a serious risk, informants saw it as distant, in both time and space, and generally considered it less important than other social or personal risks. Earlier studies demonstrate that lay attitudes towards climate change are ambivalent since the public needs to balance the demands of everyday life with awareness of the social problems caused by 
climate change (ibid.). Moreover, climate change is interpreted differently in different "interpretive communities of risk" ${ }^{2}$ defined by climate change risk perceptions, values, beliefs, media use, and policy preferences (Maibach et al., 2008).

Some studies indicate that laypeople often misunderstand both the causes and effects of climate change (e.g., Lorenzoni and Pidgeon, 2006; Lowe et al., 2006), especially when it comes to complex systems dynamics affecting climate (Sterman and Sweeney, 2002). Explanations for such misunderstandings are sought in scientific illiteracy among the public (e.g. Seacrest et al., 2000), the socio-cultural preconditions for lay understanding of climate change e.g. social norms and values (Featherstone et al., 2009; Moser, 2006), and mental models governing lay people's behavior (Sterman and Sweeney, 2002). ${ }^{3}$

The present paper locates itself among the small but increasing number of studies using social representations theory to analyze how laypeople make sense of climate change (e.g., Cabecinhas et al., 2008; Olausson, 2011; Smith and Joffe, 2012; Whitmarsh, 2011). This theory enables analyses of "how scientific knowledge is remolded and transformed into social representations, i.e. mundane understandings which are commonsensical in character" (Olausson, 2011:283). Rather than conceiving of lay interpretations of science as a problem of misunderstandings and scientific illiteracy to be overcome by science communication and education, studies starting from the social representations theory turn precisely the transformation of abstract, scientific knowledge into commonsensical understandings into the object of study (Olausson, 2011).

\footnotetext{
${ }^{2}$ An interpretive community could be defined as a subpopulation whose members "share similar perceptions, understandings, concerns, and emotional responses to global warming" (Moser, 2006: 5).

${ }^{3}$ A mental model can be defined as people's "beliefs about the networks of causes and effects that describe how a system operates, along with the boundary of the model ... and the time horizon considered relevant" (Sterman \& Sweeney, 2002: 215).
} 


\section{The theory of social representations}

Social representations theory deals with how individuals jointly form shared or partly shared representations of the surrounding world (Moscovici, 1984). In time, these representations may become transformed into common sense, i.e., a kind of everyday knowledge, by which individuals are held together and organize their social life (Chaib and Orfali, 2000). Social representations are generated through two communicative processes, i.e., objectification and anchoring (Moscovici, 1984). Through objectification, the unknown is transformed into something concrete and tangible (Bauer and Gaskell, 1999) that we can “perceive and experience with our senses" (Höijer, 2010: 719). Anchoring "makes the unknown known by bringing it into a well-known sphere of earlier social representations so that we may compare and interpret it" (Höijer, 2010: 718). Objectification is a more active process than anchoring when it comes to domesticating the unfamiliar (Moscovici, 1984), and will be the focus of the analyses presented in this paper.

The objectification process entails, according to Moscovici (1984: 40), a concept being reproduced as an image that can subsequently be decoupled from the idea to which it was originally linked and come to be perceived as an "element of reality" rather than an "element of thought". In other words, objectification entails a complex and abstract scientific phenomenon being reconstructed into something familiar, conventional, and less complicated. As soon as the phenomenon is objectified, our thinking about it becomes less reflexive and with time we are no longer aware that objectification has occurred (Marková, 1996).

One central objectification mechanism is the use of prototypical examples. Such examples are used as icons or metonymies to describe a larger phenomenon (Marková et al., 2007), 
highlighting certain aspects of the phenomenon while hiding others. In the case of climate change, the use of examples as an objectification mechanism is salient, e.g., in media discourse when particular storms or floods are ascribed to climate change (Höijer, 2010).

Another important objectifying mechanism is the use of metaphors. Metaphors are among the most powerful tools for producing new knowledge, and strongly influence how we conceive of the world around us (Lakoff and Johnson, 1980). Metaphors help construct iconic aspects that render the less familiar more familiar (Wagner et al., 1995). Metaphors highlight certain aspects of a phenomenon, concept, or situation while hiding others (Nerlich, 2010). For example, in an analysis of climate change articles published in farming magazines, Asplund (2011) found that climate change was metaphorically described in terms of a greenhouse, war, or game, each of which has different implications for how we make sense of climate change.

Although social representations theory is increasingly being seen as useful for the study of how lay people make sense of complex science-based issues, the theory is widely debated. In particular, there has been a long-standing controversy between social representations theorists and discourse theorists. While some discourse analysts acknowledge the role of social representations in maintaining and reconstructing discursive hegemonies, by arguing for instance that "in order to relate discourse and society, and hence discourse and the reproduction of dominance and inequality, we need to examine in detail the role of social representations in the minds of social actors" (van Dijk, 1993:251), others claim that social representations theory treat representations as static entities and ignores the contextual factors that influence people's knowledge construction (Potter and Litton, 1985; Radley and Billig, 1996). In response to this criticism, the present study interprets the formation and maintenance of social representations from a dialogical perspective that entails emphasizing 
the dynamic structure of representations (Marková et al., 2007). Representations can be seen as created, mediated, and negotiated via social interaction between individuals (Chaib and Orfali, 2000). In a dialogical framework, social representations are analyzed as they circulate and are elaborated in communications systems in which old and new representations coexist (Marková, 1996; Moscovici, 1984). In this respect, focus groups become opportunities for sense-making, rather than occasions when a researcher simply "taps" ready-made social representations (Marková et al., 2007).

The current study uses social representations theory to explore the following specific research questions:

- What prototypical examples and metaphors do the focus group participants use in objectifying climate change?

- What is the role of interaction with other speakers, ideas, arguments, and broader social representations in shaping the focus group participants' representations of climate change?

\section{Method and material}

The present results are based on seven qualitative focus group discussions involving 31 interviewees. A focus group is a focused group interview in which a small number of participants (4--6) discuss a given issue, under the guidance of a moderator who preferably assumes a retracted position (see e.g., Barbour and Kitzinger, 1999). The comparatively free form of discussion found in focus groups enables the researcher to discover aspects of the 
studied topic that could not have been anticipated, but that are raised spontaneously in discussion and thereby proven to be important to participants.

Focus groups were chosen since they both offer a method for analyzing what participants bring to the group and constitute "thinking societies in miniature" (Jovchelovitch, 2001: 2) in which the process of joint sense-making may be studied in action (Wibeck et al., 2007). Focus group methodology is well suited to studying social representations as they are expressed and negotiated in a group (Marková et al., 2007).

In recruiting focus group participants, I sought to achieve breadth in the data by selecting participants of various age groups and educational backgrounds (see Table 1). Each focus group, however, was internally homogeneous in terms of age and education/occupation, since this is claimed to facilitate interaction (Jarrett, 1993). Potential participants were contacted by a research assistant and invited to participate. All participants volunteered and gave their informed consent to take part of the study.

The focus group participants had a relatively high level of education; about half of the 31 participants had a finalized or ongoing university education. This is motivated by the fact that the Swedish population on average is highly educated. In Sweden today almost $50 \%$ of young people start a higher education and Sweden comes out highest in the EU when measuring the self-reported level of knowledge on the causes, consequences and ways to fight climate change (Eurobarometer, 2009). A potential bias in the data material is that most participants resided in cities and thus transportation problems were probably not as widely discussed as they might have been for instance in sparsely populated areas in Northern Sweden where there are long distances between urban regions. 
Each focus group met once and the discussions lasted 30--90 minutes. A semi-structured interview guide was used in all groups, encompassing themes such as information sources, trust in actors and institutions, and responsibility for responding to challenges posed by, for example, climate change, lifestyle, and behaviour.

Table 1. Focus groups included in the study

\begin{tabular}{|c|c|c|c|c|c|}
\hline $\begin{array}{l}\text { Group } \\
\text { no. }\end{array}$ & Participants & $\begin{array}{l}\text { Participants, no. } \\
\text { and gender }\end{array}$ & $\begin{array}{l}\text { Age } \\
\text { range }\end{array}$ & $\begin{array}{l}\text { Educational } \\
\text { background }\end{array}$ & Interview date \\
\hline FG 1 & $\begin{array}{l}\text { University } \\
\text { students }\end{array}$ & $\begin{array}{l}6 \quad(4 \text { men, } 2 \\
\text { women) }\end{array}$ & $21--23$ & $\begin{array}{l}\text { Ongoing } \\
\text { university } \\
\text { education }\end{array}$ & $\begin{array}{l}\text { October 29, } \\
2009\end{array}$ \\
\hline FG 2 & $\begin{array}{l}\text { Industry } \\
\text { workers }\end{array}$ & $\begin{array}{l}6 \quad(3 \text { men, } 3 \\
\text { women) }\end{array}$ & $52--63$ & $\begin{array}{l}\text { High school } \\
\text { education }\end{array}$ & $\begin{array}{l}\text { November } \\
2,2009\end{array}$ \\
\hline FG 3 & $\begin{array}{l}\text { University } \\
\text { teachers }\end{array}$ & $\begin{array}{l}2 \quad(1 \text { man, } 1 \\
\text { woman })^{4}\end{array}$ & $37--52$ & $\begin{array}{l}\text { University } \\
\text { degree }\end{array}$ & $\begin{array}{l}\text { November } \\
6,2009\end{array}$ \\
\hline FG 4 & $\begin{array}{l}\text { High } \\
\text { school } \\
\text { students }\end{array}$ & $\begin{array}{l}6 \quad(2 \text { men, } 4 \\
\text { women) }\end{array}$ & 17 & $\begin{array}{l}\text { Ongoing high } \\
\text { school } \\
\text { education with } \\
\text { a concentration } \\
\text { in social/ } \\
\text { natural } \\
\text { science }\end{array}$ & $\begin{array}{l}\text { November } \\
18,2009\end{array}$ \\
\hline FG 5 & $\begin{array}{l}\text { Recent } \\
\text { parents }\end{array}$ & $\begin{array}{l}4 \text { (1 man, } 3 \\
\text { women) }\end{array}$ & $33--39$ & $\begin{array}{l}\text { University } \\
\text { education }\end{array}$ & $\begin{array}{l}\text { November } \\
19,2009\end{array}$ \\
\hline FG 6 & $\begin{array}{l}\text { Sports } \\
\text { amateurs }\end{array}$ & 3 (3 men $)$ & $34--39$ & $\begin{array}{l}\text { High school } \\
\text { education }\end{array}$ & $\begin{array}{l}\text { May } \\
2010\end{array}$ \\
\hline FG 7 & Engineers & 3 (3 men) & $30--37$ & $\begin{array}{l}\text { University } \\
\text { education }\end{array}$ & $\begin{array}{l}\text { May } 24, \\
2010\end{array}$ \\
\hline
\end{tabular}

\footnotetext{
${ }^{4}$ More participants were invited to this focus group, but only two attended. Hence, this group would, according to Toner's (2009) terminology, be regarded as a "very small focus group" (VSFG). Toner argues that VSFGs may well generate rich data and that typical group development stages occur even in VSFGs, although interaction in larger groups may reflect more variation, distance, and autonomy.
} 
The focus group data were audio recorded, transcribed verbatim, and analyzed by means of “dialogical content analysis” (Marková et al., 2007: ch. 6). This type of analysis aims to capture the dynamic and interactive character of the data, rather than treating participants' utterances as static, decontextualized artifacts. Questions such as the following were taken into account in the analysis: What communicative resources ${ }^{5}$ are used in the argumentation, and how? What arguments are used, and on what explicit and implicit premises are they based? How do various types of arguments interact? What underlying values and implicit assumptions are used as shared but tacit resources in the argumentation? What values are shared? What values differ, and how?

Initial screening of the transcripts revealed that in making sense of climate change, focus group participants often used prototypical examples and metaphors as objectifying devices. Thus, I decided to focus the subsequent analysis on these communicative resources, which have also been highlighted in the social representations literature as important objectifying devices (Wagner et al., 1995; Höijer et al., 2010), along with others such as ontologization and personification (Höijer, 2010). Instances when participants used prototypical examples and metaphors were identified from the transcripts and recurrent patterns were sought. The limitation of the analysis to objectifying devices in general and prototypical examples and metaphors in particular means that some communicative resources used in the focus groups fall out of the scope of this paper, for instance analogies and distinctions, which the participants used as anchoring devices in making sense of scientific uncertainty related to climate change (see Wibeck \& Linnér, 2012).

\footnotetext{
5 'Communicative resources' are here seen as linguistic devices "enabling individuals to enter into intersubjective couplings with others, to merge their subjective worlds, thereby becoming members of groups and eventually of society at large" (Riley, 2010:59).
} 
The focus group discussions were conducted in Swedish, and all analyses treated the Swedish original transcripts; for the purposes of this paper, however, all quoted examples have been translated into English. To ensure confidentiality, all participants have been given pseudonyms.

\section{Results}

\subsection{Framing climate change as a global issue with negative consequences}

In all groups, participants saw climate change primarily as a global issue with severe consequences far away from Sweden. In every focus group, the moderator's first question was: "What do you think about when you hear the word climate change?" This question aimed to gain insight into participants' spontaneous associations with climate change, i.e., what was on top of their minds in relation to climate change. When asked this question, participants in all groups but one (FG 3) objectified climate change by citing prototypic examples (cf. Marková et al., 2007) that served to represent the entire phenomenon of climate change. Similar examples were highlighted in the groups; the most notable included melting polar ice caps, endangered polar bears, warmer weather, floods, and droughts. When asked where these images came from, participants responded that they got them from the media. This is well in line with what media studies have found, i.e., that the Swedish media tend to report on climate change according to a frame of scientific certainty, emphasizing extreme weather events already occurring as evidence of climate change (Olausson, 2009). It is probably not surprising that media images were reproduced in the focus group discussions. As far as climate change is concerned, mass media are seen as important actors in influencing public awareness and opinion (e.g., Nisbet, 2009; O’Neill and Nicholson-Cole, 2009; Ryghaug et al., 2011). The images used as examples in the 
focus groups contributed to highlighting some aspects of climate change, while concealing others.

The examples of melting polar ice caps, endangered polar bears, floods, and droughts emphasize the urgency of climate change and its potentially life-threatening and irreversible consequences. Doyle (2007: 129) notes that images of melting glaciers are "powerful symbols of a fragile earth at risk from the impacts of climate change." However, these examples also frame climate change as a global issue with far-away consequences difficult for a layperson to influence through everyday behaviour. Doyle (2007: 142) argues that "such images produce a distancing effect, relegating climate change impacts to a remote and inaccessible place, where animals and habitats are affected rather than humans." It is worth noting that when discussing climate change impacts, the participants often mentioned severe, life-threatening effects such as floods and droughts in developing countries, but responses to climate change were often framed as a matter of individual actions such as sorting household waste, turning off the lights when leaving a room or refraining from flying on vacations. The participants seemed concerned about the lack of proportion between the serious consequences of climate change and the uncertain effects of personal mitigation efforts (Wibeck \& Linnér, 2012).

It is noteworthy that the focus group participants' use of prototypical examples was not static. In objectifying climate change, such examples were often established only after a process of negotiation between participants, as illustrated in the following excerpt from the group interview with university students:

Excerpt $1^{6}$

\footnotetext{
${ }^{6}$ The following transcription conventions have been used: boldface signals emphasis, underlining signals simultaneous speech, (.) signals a very short pause, * signals that the speaker is laughing, and [XXX] signals an
} 
1 Moderator: For a start, what do you think of when I say the word "climate change"? What comes to mind?

$2 \quad$ Fanny: $\quad[\mathrm{XXX}]$ the ice, it's melting more and more, that is the first thing I think of. That's what most people talk about, [X: umm] or at least that's how I understand it (.)

$3 \quad \mathrm{X}:$

The ice, yeah

4 Björn:

Then there will be a lot of (.) floods---it's something I think about a lot---in Bangladesh and Sri Lanka and that area $[\mathrm{XXX}]$

5 Anders: $\quad$ Yeah, yeah, but I think more about how it will get warmer [X:

$\mathrm{mmm}]$, so for me it's a bit positive in a way

6 Elin: $\quad$ But it's the heat that makes the ice melt

$7 \quad$ Anders: $\quad$ That's true [X: Yes], but we kind of have enough of ice, one might feel

$8 \quad$ Laughter

$9 \quad$ Christer: $\quad$ Especially in Sweden $[\mathrm{XXX}]$

$10 \quad$ Anders: $\quad$ Yes

11 Elin: $\quad[\mathrm{XXX}]$ when the ice melts more and more, the water will start to rise

12 Anders: $\quad$ Yes

13 Björn: What I think about ... many people use the argument that it will get hotter, but (.) it will get hotter here, but it will become worse for those who already live in hot places. There it will be even hotter---I mean drought or there will be floods

14 Anders: $\quad$ Yes absolutely. But then it will also become ... sure there is a 
disadvantage with that as well, namely, that these areas will be very attractive [Björn: yes] precisely to (.) grow things, and then we will have very large movements, migrations, and that is probably not so good [Björn: No] (.) absolutely not

Excerpt 1 illustrates how the focus group participants jointly constructed their representations of climate change. In turn 2, Fanny responds to the moderator's initial question about the first things that come to mind when thinking about climate change. Fanny mentions the melting polar ice, and refers to an anonymous collective of people who see melting glaciers as the most severe consequence of climate change. However, she immediately hedges her statement by saying that at least that is what she has perceived as being identified as a main concern. She is supported in this view by another participant in turn 3. In turn 4, Björn mentions another effect of climate change, i.e., floods that will affect countries such as Bangladesh and Sri Lanka. Anders takes over in turn 5 and introduces another perspective on climate change, i.e., that it could have positive consequences in that the temperature will increase, apparently thinking about conditions in Sweden. His view is contested by Elin in turn 6, who claims that increasing temperatures will lead to the melting of glaciers, which was earlier identified as a negative consequence. Anders responds to this by jokingly referring to the cold winters in Sweden (turn 7), a view co-constructed with Christer in turn 9. Elin, however, appears to take no notice of this, but reinforces her statement that melting ice will lead to a sea level rise. Anders now starts to modify his earlier claim, and concedes to Elin's statement about sea level rise (turn 12). In turn 13, Björn aligns himself with Elin in criticizing the claim that climate change will positively affect Sweden by warming the winters. Rather than taking just local effects into account, Björn refers to the consequences for people in Southern countries, who will be the 
victims of droughts and flooding. At this point in the discussion (turn 14), Anders modifies his previous statement and emphasizes that if Sweden becomes warmer, it will become attractive to refugees from more vulnerable areas, which he sees as problematic.

This excerpt illustrates how prototypical examples such as melting polar ice and floods are raised in the discussion. Although local effects of climate change are discussed, the participants eventually agree that the global consequences are the biggest problems. Hence, excerpt 1 also illustrates how representations of climate change are negotiated and coconstructed in dialogue between participants. This process illustrates the dynamic character of social representations, which can be seen as being constructed, elaborated, and upheld in interaction between participants. I argue that to understand how social representations of climate change are objectified, it is insufficient merely to study what examples the focus group participants bring into the discussion, but also to analyze how these examples are presented to and received by the other participants. In what context is the example cited? Is it used to try to make sense of climate change or as an argument for a particular standpoint? Does it represent a response to a previous utterance, or is it the starting point of a new exchange of meaning? Is it agreed on by the focus group participants or is it contested?

Although the severe and distant consequences of climate change were dominant in the focus group discussions, as illustrated in Excerpt 1, on some occasions participants also discussed local impacts. In some of the groups (FG 1, 2, 4 and 5), examples such as the participants' own experiences of changes in weather, in particular mild winters with lack of snow and hot or rainy summers, were taken as a signal of a changing climate. However, in FGs 1, 2 and 4, the participants disagreed about whether higher temperatures were a consequence of anthropogenic climate change or of natural fluctuations in climate. The 
consequences for Sweden were also seen to be much less severe and more easily managed than impacts in developing countries already suffering from poverty. This suggests that social representations should not be analyzed in isolation. To understand how people make sense of climate change, I argue that it is important not to decontextualize an utterance in a focus group, e.g. about local impacts on weather conditions, but to pay attention to how the interaction between thoughts and ideas expressed in the focus groups throughout the conversation forms the social representations, and how the representations expressed and negotiated among focus group participants interact with broader social representations circulating e.g. in media or political debates.

\subsection{Climate change causes, effects, and responses: gradual or unpredictable processes?}

Another objectifying device recurrently used by focus group participants was the metaphor. Metaphors are central to the process of objectifying a phenomenon, since they make abstract knowledge concrete and conceivable in everyday talk (Wagner et al., 1995). Through using metaphorical language, focus group participants constructed various images of the causes and effects of climate change, and of human responses to it.

The metaphorical language used by focus group participants helped shape social representations of climate change in accordance with what Szerszynski and Urry (2010) label gradualism and catastrophism. Gradualism "involves the claims that climates are changing around the world, that human activities are significantly if not entirely responsible for these changes, that these changes are relatively slow, and that economies will be able to adjust in order to reduce them and adapt to them" (Szerszynski and Urry, 2010: 1--2). Gradualism emphasizes human responses to climate change that are based on risk calculation and 
behavior change supported by appropriate economic incentives. Catastrophism, in contrast, entails a focus on "non-linearity, thresholds and abrupt and sudden change" (Szerszynski and Urry, 2010: 2). Catastrophism acknowledges climate change as a fact, while also emphasizing scientific uncertainty and the limits of scientific knowledge. In terms of responses to climate change, catastrophism presumes that climate change is already happening and that little can be done to stop its progress.

Gradualism was expressed through metaphors emphasizing movement ${ }^{7}$, such as "Earth is on its way to getting warmer (FG 1)", "taking small steps forward (FG 1)", “go back,” (FG 1) and "move forward" (FG 1, FG 7). Metaphors indicating location, such as "on the leading edge" (FG 6) and "the aviation industry is lagging behind in fuel efficiency" (FG 7), and speed metaphors, such as "move slowly (FG 4)", "go fast (FG 1, FG 6)," and "slow down" (FG 1), were also used. Movement and speed metaphors imply a rational agent who may "think ahead" (FG 3) and decide whether or not to move, go quickly or slowly, and take steps backward or forward. It was also suggested that powerful actors should "show the way" to the public (FG 3), which suggests that the right way is known and that what is needed are guides who can lead others in the right direction.

Returning to the group of university students, we find the following example in which metaphors are used to objectify climate change as being about gradual changes:

\section{Excerpt 2}

\footnotetext{
${ }^{7}$ Even though the expressions 'go back' and 'move forward' are often used in a literal sense, they are used metaphorically in the focus group context, to describe processes of climate change and approaches to climate change mitigation and adaptation. Such orientational metaphors are of special interest as they are used nonmetaphorically; they are powerful since speakers rarely reflect on their metaphorical status (Lakoff and Johnson, 1980).
} 
Björn: $\quad$ Yes, but what I mean is that when it happens, it will not happen overnight, it will certainly happen in stages [X: um]. And then maybe when it has reached the level that (.), okay, now we won't be able to live in Sweden anymore, or in Holland, or we can't live there, so we move (.) I mean human beings adapt

2 Elin: But it is still worth fighting for, to sort of (.) get this process to advance more slowly. Isn't that something we should fight for, not to make it go faster anyway?

In this excerpt, climate change is seen as something that can be predicted and then affected through mitigation measures. At the same time, adaptation measures are also pinpointed. In turn 1, Björn talks about "stages" and "levels" to describe the gradual nature of climate change. Björn also constructs the image of humans as responding in rational ways to climate change through deliberate adaptation: when some countries become so affected by climate change that it is impossible to live there, people will adapt to this by moving. In turn 2, Elin also constructs the image of a gradually changing climate, but rather than highlighting adaptation, she emphasizes the importance of mitigating climate change. Even though global warming cannot be entirely stopped, Elin argues that it is important to "fight" to slow the process. Here, Elin invokes a war metaphor by using the term "fight," which connotes an active agent working mainly on mitigation measures (cf. Asplund, 2011). In addition to the war metaphor, Elin uses metaphors related to movement and speed; the process should be made to "go more slowly" rather than "go quicker." In using such speed and movement metaphors, climate change is objectified as something that can be governed by humans. 
When the focus group participants used metaphorical language to objectify climate change as a gradual process that could be handled by taking rational measures to mitigate and adapt, their argumentation seems to be based on implicit assumptions related to a modernist worldview, emphasizing progress and rationality. However, other parts of the focus group discussions appeared to build on another, contradictory assumption, that climate change is unpredictable and chaotic, as are human responses to it. Metaphoric expressions such as "the snowball is rolling" (FG 1), "Earth goes in cycles, and suddenly it turns around and goes down again” (FG 2), “it goes up and down” (FG 4), “the temperature is rising, we don't know how fast but it will accelerate" (FG 6), governments have been forced to "wake up" (FG 2), and "everyone is running around with a collective paranoia" (FG 1) were used to describe this process. These expressions convey the sense of an unprepared humanity being surprised by sudden and unforeseen changes in the environment.

The use of metaphors in objectifying climate change is by no means neutral (Lakoff and Johnson, 1980). Representing climate change as a gradual process plays well with broader social representations of climate change as a moral issue (Koteyko et al., 2010; Nisbet and Scheufele, 2009) which demands collective action (Olausson, 2009). Two contrasting tendencies can be found in global environmental politics, both resting on gradualist assumptions. The last two decades have seen increasing focus on individual responsibility for mitigation of environmental stress (Skill and Gyberg, 2010). On the other hand, state responsibilities, policies, and action measures are still emphasized (Linnér and Lövbrand, 2011), for example when it comes to introducing higher carbon prices to govern industrial investments and consumer behavior (IPCC, 2007). Both types of argument presuppose that climate change can be predicted and that rational actors may influence its course by deliberate mitigation actions. By contrast, catastrophism might paradoxically play in the hands of 
climate skeptics, since it could legitimize inaction based on the claim that processes of climate change are unpredictable and impossible to prevent.

It is noteworthy that both gradualist and catastrophist assumptions often coexisted in the same focus group discussion, even sometimes both expressed by the same participant. The following excerpt from the focus group consisting of high school pupils illustrates this dynamic tension between gradualism and catastrophism:

\section{Excerpt 3}

$1 \quad$ Erik: $\quad$ But it's too late (.) We can't (.) we can slow it down but we can't stop it. Maybe we could ten years ago. But now it's really too late, now (.) it will just break down and break down but we can still slow it down so it will take very long.

2 Carina: It will never be like it was before.

3 Erik: $\quad$ No (.) that's why I feel that (.) but maybe if there had been a limit that (.) well we can make it, it will sort of go upwards again and rebuild again (.) but that's not possible.

(23 turns omitted)

$4 \quad$ Annie: $\quad$ But, there are so many who say different things, some say that (.) well if everybody helps it will kind of get well

In turn 1, Erik uses metaphors which bring about connotations to vehicles which can be stopped, slowed down or broken. The argument that climate change could be "slowed down" has gradualist roots and implies that mitigation could have an impact on climate change which would buy societies some time to adapt. On the other hand, both Erik and Carina argue that a 
tipping point (to use another metaphor frequently used in popular climate science) has been passed and that climate change is now irreversible. The unpredictability of climate change is underscored by Carina in turn 2, when she argues that "it will never be like it was before", i.e. the impacts of climate change could not be understood by comparing to familiar life conditions. The metaphor of a "limit" is introduced by Erik in turn 3, when he laments that there is no known limit before which it would have made sense to strive to mitigate climate change. Instead, he concludes with the catastrophic view that it is impossible for the climate to "rebuild". Later in the focus group discussion, however, Erik's pessimistic view is contested by Annie, who states that there is uncertainty among experts. Contrary to what Erik said in turn 1, in turn 4 Annie invokes a more radical gradualist view, where human responses to climate change would actually contribute to reverse its course.

Excerpt 3 is one illustration of the coexistence and dynamic tension between gradualism and catastrophism in the focus groups. A main function of social representations, according to Moscovici (1984), is to conventionalize objects, people, and events, i.e., to place the unknown in familiar contexts, making it understandable to the layperson. I argue that the coexistence of gradualism and catastrophism in the focus groups could be interpreted as indicating an ongoing conventionalization in which various interpretations of climate change causes, effects, and responses are under negotiation. This is particularly interesting in contrast to the Swedish news media, which frame climate change relatively unanimously as a matter of scientific certainty (Olausson, 2009). Earlier surveys depicted the Swedish public as relatively certain about the causes, impacts and ways of responding to climate change (Eurobarometer, 2009). However, even though most focus group participants shared the basic assumption that climate change has anthropogenic causes, there was still room for different interpretations of how to understand climate change, its causes, effects and potential responses. In this 
conventionalization process, metaphors seem to play an important role as objectifying devices rendering climate change more concrete to focus group participants. This further reinforces that it is important not only to ask what people think about climate change, but also to analyze their arguments in greater depth.

\section{Discussion}

This paper shows how the focus group participants used prototypical examples and metaphorical descriptions to make sense of climate change. The prototypical examples most frequently used by the focus group participants served the function of objectifying climate change as a global but distant issue with severe consequences hard for a Swedish lay person to influence. These examples included melting polar ice caps, droughts and floods in developing countries. Metaphorical descriptions used by the participants were mainly of two types. One type included movement and speed metaphors, which helped construct climate change as a gradual process that could be handled by rational actors taking steps to mitigate emissions and adapt to the impacts of global warming. Another, contrasting, type of metaphorical descriptions helped objectifying climate change as unpredictable, characterized by sudden changes in the environment which are hard to counteract or prevent.

Using prototypical examples and metaphorical descriptions as communicative resources, participants constructed, modified, and negotiated their understanding of climate change. The study illustrates how objectification processes help shape the content of social representations, further demonstrating how interaction affects objectification. What we think and how we argue about climate change are not only matters of personal opinion; our representations of climate change are largely formed and maintained in interplay with others, with what is communicated in the media, and with broader scientific and political representations. As 
argued by Marková et al. (2007: 133), interaction can be analyzed on at least three levels, i.e., a) between "speakers and interlocutors in the situated encounter," b) between "thoughts, ideas and arguments in the discursive or textual web that is generated by participants," and c) in " 'interaction with sociocultural traditions', i.e., the interdependence between different discourses (ways and traditions of talking about the issue) and between the communicative genres involved." I argue that, when analyzing social representations, all three levels of interaction should be taken into account. The focus group data clearly indicated that interaction between participants shapes their representations, in that participants try out and negotiate the use of objectifying devices. However, this is also a question of interaction between arguments and with sociocultural traditions. The metaphors used by focus group participants helped reconstruct broader social representations of gradualism and catastrophism. On other occasions, the objectifying devices used in the interaction between individual focus group participants interacted with the sociocultural level by reproducing climate change in terms of images frequent in media and popular culture. In this respect, the present study adds to earlier studies of public engagement in climate change, which have pointed to the importance of sociocultural factors such as social norms, ideologies and values, in influencing public engagement with climate change (e.g. Hulme, 2009; Lorenzoni et al., 2007b; Whitmarsh et al., 2011).

Taking seriously the role of interaction in shaping social representations has implications for the public communication of climate change. Many efforts to communicate climate change still appear to be inspired by the much criticized "deficit model" of science communication (Brossard and Lewenstein, 2009; Nisbet and Scheufele, 2009). This model assumes that laypeople will need additional knowledge, acquired, for example, through science education and science communication, if they are to regain trust in scientific authorities and change their 
lifestyles to favor more climate-friendly behavior. This focus on information transfer, however, neglects the role of the addressee as an active participant in interpreting climate change messages in accordance with previous experience, in analogy with other societal problems, and in interaction with a variety of information sources. It also largely neglects the role of sociocultural factors in influencing public engagement, as discussed above. I argue that climate change communicators should use communication fora that enable addressees to become active in the communication process, facilitating dialogue about climate change causes, effects, uncertainties, and responses. Although dialogue is generally seen as a desirable feature of science communication (Rodari, 2008), in my view this is particularly important for climate change communication, given that climate change will largely affect the public, and the public needs to be engaged in responding to it in different ways, both by mitigation and adaptation.

Earlier studies of climate change communication have emphasized the importance of the communicator's segmenting target groups and taking their interpretative frames into account (e.g., Featherstone et al., 2009; Maibach et al., 2008). As pointed out by Moser (2010: 39), "different audiences require distinct frames, goals, messages, and messengers." The present study emphasizes that the public's understanding of climate change messages is influenced by e.g. previous knowledge and experience, everyday interactions with people, media messages, and scientific and political debate on climate change. In line with Maibach et al. (2008), I advocate analyzing target audiences' values and worldviews and trying to identify “interpretive communities" sharing similar social representations of climate change.

Finally, the role of images---visual images and metaphors---in climate change communication should not be underestimated. As noted above, media images of distant 
melting ice caps and floods tended to be reproduced in interactions between focus group participants. However, earlier studies have shown that messages perceived as containing information relevant to individual receivers, emphasizing local effects and concrete action strategies, are more likely to motivate and engage the audience (Nicholson-Cole, 2005; O’Neill \& Nicholson-Cole, 2009). Complementing the images which present climate change as a distant issue with negative consequences with new pictures and metaphors focusing on solutions and responses at the local and personal levels is an important challenge facing climate change communicators.

\section{Acknowledgements}

This paper was made possible by a grant from the Swedish Research Council for the project Making sense of climate change - a study of the formation and maintenance of social representations (project no. 2008-1723). The author wishes to thank Jeanette Andersson, Tommy Rosén, and Hanna Rosenqvist for assistance in recruiting the focus groups. Thanks are also extended to Tommy Rosén for transcribing the focus group data, to Therese Asplund, Eva Lövbrand and two anonymous reviewers for their valuable comments on earlier drafts of the paper, and to the focus group participants for sharing their thoughts about climate change.

\section{References}

Asplund T (2011) Metaphors in climate discourse: an analysis of Swedish farm magazines. Journal of Science Communication 10(04):A01.

Barbour R, Kitzinger J (eds) (1999), Developing focus group research: Politics, theory and practice. London: Sage.

Bauer M, Gaskell, G (1999) Towards a paradigm for research on social representations. Journal for the Theory of Social Behaviour 29(2):163--186. 
Brossard D, Lewenstein B (2009) A critical appraisal of models of public understanding of science. In: Kahlor L and Stout P (eds.), Communicating science: New agendas in communication. New York: Routledge.

Cabecinhas R, Lázaro A, and Carvalho A (2008) Media uses and social representations of climate change. In: Carvalho, A (ed.), Communicating climate change: discourses, mediations and perceptions. Braga: Universidade do Minho.

Carvalho A (2008) The challenges of communicating climate change. In: Carvalho, A (ed.), Communicating climate change: discourses, mediations and perceptions. Braga: Universidade do Minho.

Chaib M, Orfali B (2000) Preface. In: Chaib M and Orfali B (eds.), Social Representations and Communicative Processes. Jönköping: Jönköping University Press.

Doyle J (2007) Picturing the clima(c)tic: Greenpeace and the representational politics of climate change communication. Science as Culture 16(2):129--150.

Eurobarometer (2009) Europeans' attitudes towards climate change. Special Eurobarometer 313. URL: http://ec.europa.eu/public_opinion/archives/ebs/ebs_313_en.pdf

Eurobarometer (2011) Europeans' attitudes towards climate change. Special Eurobarometer 372. URL: http://ec.europa.eu/public_opinion/archives/ebs/ebs_372_en.pdf.

Featherstone H, Weitkamp E, Ling K and Burnet F (2009). Defining issue-based publics for public engagement: climate change as a case study. Public Understanding of Science 18(2):214--228.

Hassol S (2008) Improving how scientists communicate about climate change. Eos Trans. AGU 89(11):106.

Hulme M (2009) Why we disagree about climate change: understanding controversy, inaction and opportunity. Cambridge: Cambridge University Press. 
Höijer B (2010) Emotional anchoring and objectification in the media reporting on climate change. Public Understanding of Science 19(6):717--731.

IPCC (2007) Climate Change 2007: Synthesis Report. Cambridge: Cambridge University Press.

Jarrett R (1993) Focus group interviewing with low-income minority populations. In: Morgan D (ed.) Successful Focus Groups. Advancing the State of the Art. Newbury Park: Sage. Jovchelovitch S (2001) Contextualising focus groups: understanding groups and cultures. Paper for the V meeting of "Conversation et language," Laboratoire Européen de Psychologie Social, Paris.

Lakoff R, Johnson M (1980) Metaphors we live by. University of Chicago Press, Chicago. Leiserowitz A, Maibach E, Roser-Renouf C, and Smith N (2011) Climate change in the American mind. New Haven: Yale University and George Mason University. Linnér B and Lövbrand E (2011) (Re)producing transnationalism: examining the state of climate governance through UN side events. Paper for International Studies Association Annual Convention, Montreal.

Lorenzoni I, Pidgeon N (2006) Public views on climate change: European and USA perspectives. Climatic Change 77(1-2):73-95.

Lorenzoni I, Jones M, Turnpenny J (2007a) Climate change, human genetics, and postnormality in the UK. Futures 39(1): 65--82.

Lorenzoni I, Nicholson-Cole S, Whitmarsh L (2007b) Barriers perceived to engaging with climate change among the UK public and their policy implications. Global Environmental Change 17(3):445-459.

Lowe T, Brown, K, and Dessai S (2006) Does tomorrow ever come? Disaster narratives and public perceptions of climate change. Public Understanding of Science 15(4):435--457. 
Maibach E, Roser-Renouf C, and Leiserowitz A (2008) Communication and marketing as climate change-intervention assets. A public health perspective. American Journal of Preventive Medicine 35(5):488--500.

Marková I (1996) Towards an epistemology of social representations. Journal for the Theory of Social Behaviour 26(2):177--196.

Marková I, Grossen M, Linell P, and Salazar Orvig A (2007) Dialogue in focus groups: exploring socially shared knowledge. Equinox: London.

Moscovici S (1984) The phenomenon of social representations. In: Farr R and Moscovici S (eds.) Social Representations. Cambridge: Cambridge University Press.

Moser S (2006) Talk of the city: engaging urbanites on climate change. Environmental Research Letters 1(1):1--10.

Moser S (2010) Communicating climate change: history, challenges, process and future directions. WIREs Climate Change 1(1):31--53.

Nerlich B (2010) 'Climategate': paradoxical metaphors and political paralysis. Environmental Values 19(4): 419--442.

Nicholson-Cole S (2005) Representing climate change futures: a critique on the use of images for visual communication. Computers, Environment and Urban Systems 29(3):255--273.

Nisbet M (2009) Communicating climate change: Why frames matter for public engagement. Environment 51(2):12--23.

Nisbet M, Scheufele D (2009) What's next for science communication? Promising directions and lingering distractions. American Journal of Botany 96(10): 1767--1778.

O’Neill S, Nicholson-Cole S (2009) 'Fear won’t do it': Promoting positive engagement with climate change through visual and iconic representations. Science Communication 30(3):355--379. 
Olausson U (2009) Global warming---global responsibility? Media frames of collective action and scientific certainty. Public Understanding of Science 18(4):421--436.

Olausson U (2011) 'We're the ones to blame': Citizens' representations of climate change and the role of the media. Environmental Communication 5(3):281--299.

Potter J, Litton I (1985) Some problems underlying the theory of social representations. British Journal of Social Psychology 24(2):81--90.

Radley A, Billig M (1996) Accounts of health and illness: Dilemmas and representations. Sociology of Health and Illness 2(2):220--240.

Riley P (2010) Proverbial wisdom and personal experience: exploring the social epistemology of communicative practices. Vienna English Working Papers 19(1-2):47-63.

Rodari P (2008) The frontiers of dialogue, JCOM 07(01):C01.

Ryghaug M, Holtan Sorensen K, and Naess R (2010) Making sense of global warming: Norwegians appropriating knowledge of anthropogenic climate change. Public Understanding of Science 19(6):1--18.

Schneider R (2011) Climate change: an emergency management perspective. Disaster Prevention and Management 20(1):53--62.

Seacrest S, Kuzelka R, Leonard R (2000) Global climate change and public perception: the challenge of translation. Journal of the American Water Resources Association 36(2):253-263.

SEPA (2004). The Swedish climate campaign---part of Sweden's climate strategy. Stockholm: Naturvårdsverket.

Smith N, Joffe H (2012) How the public engages with global warming: a social representations approach. Public Understanding of Sicence. DOI:10.1177/0963662512440913 Sterman J, Sweeney L (2002) Cloudy skies: assessing public understanding of global warming. System Dynamics Review 18(2):207--240. 
Szerszynski B, Urry J (2010) Changing climates: Introduction. Theory, Culture and Society 27(2--3):1--8.

Toner J (2009) Small is not too small: Reflections concerning the validity of very small focus groups (VSFGs). Qualitative Social Work 8(2):179--192.

UNEP (2011). UNEP climate change strategy. URL:

http://www.unep.org/pdf/UNEP_CC_STRATEGY_web.pdf

Van Dijk T (1993) Principles of critical discourse analysis. Discourse \& Society 4(2):249-283.

Wagner W, Elejabarrieta F, and Lahnsteiner I (1995) How the sperm dominates the ovum: objectification by metaphor in the social representation of conception. European Journal of Social Psychology 25(6):671--688.

Westander H, Henryson J, Lindberg J (2008) Media och klimatförändringen. Stockholm: Westander Publicitet \& Påverkan.

Whitmarsh L, Seyfang G, O’Neill S (2011) Public engagement with carbon and climate change: To what extent is the public 'carbon capable'? Global Environmental Change 21(1):56-65.

Wibeck V (forthc.) Who are the learners of climate change? A review of literature on climate change communication and public engagement. Submitted manuscript.

Wibeck V, Öberg G, and Abrandt-Dahlgren M (2007) Learning in focus groups: an analytical dimension for enhancing focus group research. Qualitative research 7(7):249--262.

Wibeck V, Linnér B (2012) Public understanding of uncertainties in climate science and policy. In: Ibisch P, Cybulla F, and Geiger L (eds.) Global change management: knowledge gaps, blindspots and unknowables. Nomos, Berlin. 
